\title{
Damselfish territories: zones of high productivity on coral reefs
}

\author{
D. W. Klumpp, D. McKinnon, P. Daniel \\ Australian Institute of Marine Science, PMB No. 3, Townsville M. C., Queensland 4810, Australia
}

\begin{abstract}
Temitories of 4 species of herbivorous damselfish from coral reefs of the central Great Barrier Reef and Motupore Island, Papua New Guinea were shown to be zones of high algal biomass and primary productivity relative to surrounding epilithic algal communities. Productivity was measured in the field from diel patterns in oxygen flux, employing in situ data-logging respirometers. Algal communities inside territories were 1.6 to 3.4 times more productive per surface area than surrounding algal substrata. Algal communities of damselfish territories maintain a rate of productivity per unit biomass 1.5 to 3.4 times higher than that of algae growing outside the territories. Differences in primary productivity for the 2 different types of algal community are due to the higher photosynthetic efficiency ( 0.37 to $0.94 \mu \mathrm{g} \mathrm{O}_{2} \mu \mathrm{E}^{-1}$ ) and potential maximum rate of photosynthesis (57 to $249 \mu \mathrm{g} \mathrm{O} \mathrm{Cm}^{-2} \mathrm{~h}^{-1}$ ) of algae from territories compared with algae of non-territory areas $\left(0.20\right.$ to $0.35 \mu \mathrm{g} \mathrm{O}_{2} \mu \mathrm{E}^{-1}$ and 24 to $78 \mu \mathrm{g}$ $\mathrm{O}_{2} \mathrm{~cm}^{-2} \mathrm{~h}^{-1}$, respectively). Photosynthetic compensation and saturation irradiance were similar for the 2 algal communities and ranged from 52 to 100 and 337 to $735 \mu \mathrm{E} \mathrm{m}^{-2} \mathrm{~s}^{-1}$, respectively. These territories are shown to be important to reef net productivity since they cover a high proportion of the reef flat zones examined (up to $77 \%$ of substratum). Several hypotheses are proposed to account for the significantly higher rates of primary productivity inside coral reef damselfish territories compared with adjacent substrata.
\end{abstract}

\section{INTRODUCTION}

The epilithic algal communities of coral reefs, although inconspicuous and of low biomass, are now known to be highly productive (Smith \& Marsh 1973, Marsh 1976a, Carpenter 1985). Most important to reef trophic processes, these algae are high net producers of carbon (Wanders 1976, Carpenter 1985, Russ in press) supplying the vast proportion of the food requirements of abundant grazers (Carpenter 1981, Rogers \& Salesky 1981, Williams 1981, Hatcher 1982, Hixon 1983, Carpenter 1986). Many estimates of primary productivity for these all-important reef algal communities were based on laboratory measurements of instantaneous rates of production. Models of primary productivity constructed from long-term studies, incorporating where possible the complexities of natural environmental conditions, such as initiated by Carpenter $(1985,1986)$, are now desirable.

Epilithic algae of coral reefs are kept closely cropped by the grazing and scraping action of large numbers of

Contribution No. 382 from the Australian Institute of Marine Science herbivores; mainly fishes in the Indo-Pacific (Hixon \& Brostoff 1981, Hatcher 1982, 1983, Russ in press) and fishes plus echinoids in the Caribbean (van den Hoek 1969, Ogden \& Lobel 1978, Williams 1981, Carpenter 1986). Notable exceptions are the defended territories of herbivorous damselfish in which relatively luxuriant patches of filamentous algae can occur (Vine 1974, Brawley \& Adey 1977, Lassuy 1980, Williams 1981, Ruyter van Steveninck 1984, Russ in press). Numerous studies have demonstrated that these patches of algae usually have a different community structure, and often a higher diversity, compared with the adjacent substratum (see e.g. Brawley \& Adey 1977, Lassuy 1980, Sammarco 1983, Kamura \& Choonhabandit 1986). Brawley \& Adey (1977) were the first to propose that reef substrata colonized by these fish territory algae would be more productive on an equivalent area basis than the surroundings, based on their unpublished observations that turfs are highly productive compared with other reef algae and that biomass of algal turfs was higher inside territories of damselfish Eupomacentrus $=$ Stegastes planifrons.

Montgomery (1980) actually measured photosynthetic rate, using the $\mathrm{O}_{2}$-light-dark bottle incubation 
technique, as well as standing crop of algae defended by a territorial damselfish, Microspathodon dorsalis, inhabiting rocky reefs of the Gulf of California, and compared this with the surrounding 'algal mats'. In contrast to the usual coral reef situation, the territorial substratum was a near monoculture of Polysiphonia sp., and had 13 to 26 times less biomass per surface area than the multispecies algal mat. Despite these differences in biomass the fish territory algal community was estimated to be 2.5 times more productive than an equivalent area of algal mat. Estimates of the rate of algal biomass accumulation inside and outside damselfish territories on coral reefs have been published only by Russ (in press). Production of algae, or yield in this case, was estimated from changes in algal biomass on coral plates before and after caging. This work supported Montgomery's findings that territory algae are more productive than non-territory algae on a surface area basis; however the differences observed by Russ were not statistically significant.

Early in our research on the productivity of the epilithic algal communities of the central Great Barrier Reef it was apparent that much of the variability in productivity could be accounted for by the presence of algal-rich herbivorous damselfish territories. Preliminary observations indicated that these territories were more active photosynthetically than other reef algal substrate. We here attempt to quantify these differences in reef epilithic algal community metabolism and to assess the significance of these in the context of total reef primary productivity. Specifically, we compared the rates of primary productivity of substrata from within territories of 4 species of damselfish, inhabiting reefs from nearshore to the outer continental shelf margin, with that of adjacent external substrata. The distribution and comparative cover of damselfish territories were examined in detail for Davies Reef, located on the mid-shelf of the Great Barrier Reef.

\section{MATERIALS AND METHODS}

Substratum selection. Primary productivity of epilithic algal communities occurring inside and adjacent to herbivorous damselfish territories on reef flats (depth 1 to $2 \mathrm{~m}$ ) at Davies and Myrmidon Reefs in the central Great Barrier Reef (GBR) and on the fringing reef of Motupore Island, Papua New Guinea (Fig. 1) were compared. Primary productivity was estimated from in situ diel measurements of photosynthetic and respiratory rates using the oxygen technique. Territories of 2 species of damselfish were examined at Davies Reef: Stegastes apicalis, the most abundant damselfish on mid-shelf reefs of the GBR, and S. nigricans, one of the most aggressive territorial fishes found

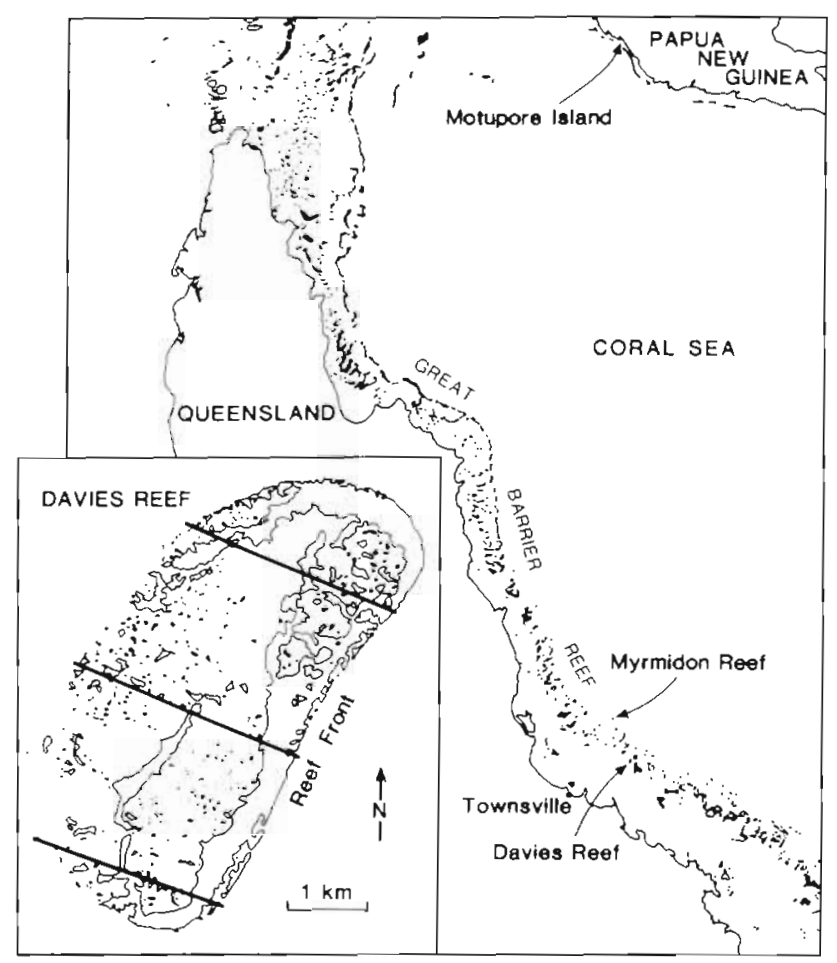

Fig. 1. Reefs where primary productivity was measured: Davies and Myrmidon Reefs and Motupore Island. Lines on the enlargement of Davies Reef depict the northern, central and southern sections along which the 14 sites were surveyed for substratum composition. Actual locations of the 14 crossreef transect sites (from front reef slope to back reef slope) are described in 'Materials and Methods'

on coral reefs. The territories of both these species occur typically on reef flats where there is some relief in the substratum. In the present study we chose substrata for productivity measurements from among dead branching Acropora sp., as this material was convenient for the measurement of surface area and algal biomass. The most common herbivorous damselfishes in shallow waters of Myrmidon and Motupore Island reefs were S. fasciolatus and Plectroglyphidodon lacrymatus, respectively. The territories of $P$. lacrymatus occupy most of the dead coral substratum on the reef flats of Motupore Island. Algal productivity inside and adjacent to the territories of these 2 species was measured using square blocks $(8 \times 8 \times 2 \mathrm{~cm})$ of Porites which had been attached to the respective reef substrata for a period of 12 mo prior to measurement.

In a separate experiment coral blocks with an established algal covering from non-territory substrata were caged with wire mesh $(1.5 \times 1.5 \mathrm{~cm})$ for $30 \mathrm{~d}$ during April on the reef flat at Davies Reef, thereby excluding all large grazers and resulting in an increase in algal biomass. After this period, the productivity of algae on these blocks was measured by respirometry and compared simultaneously with that of uncaged blocks. The 
caging treatment has been used by Russ (in press) as a method for estimating rates of algal biomass accumulation on the Great Barrier Reef and furthermore, has been shown by Russ (in press) and Scott \& Russ (1987) to result in no cage effects on either algal growth or community structure other than that of excluding grazers.

Algal productivity by respirometry. Primary productivity of the above algal samples was measured using 3 in situ respirometers (Fig. 2) which were designed and constructed at the Australian Institute of Marine Science (AIMS). These instruments consist of 2 basic parts: an electronics compartment housed inside a PVC cylinder that is watertight to depths of $30 \mathrm{~m}$; and a set of 4 perspex respirometer chambers each of $1.76 \mathrm{l}$ capacity, with associated instrumentation for monitoring light as photosynthetic-photon flux density or irradiance (Li-cor underwater quantum sensor, L1192S), temperature and oxygen concentration (KentEIL galvanic sensor). Oxygen sensors were calibrated with air-equilibrated and deoxygenated (sodium dithionite) seawater kept at constant temperature. A microprocessor (developed by AIMS) in the electronics compartment controls automatic operation of the machine and data logging. During operation the water inside each perspex respirometer chamber was stirred continuously by propellor and also flushed by the pump at predetermined intervals. The measured parameters of light, temperature and oxygen concentration were logged into memory at intervals of 1 to $255 \mathrm{~min}$. Similarly, the intervals at which the chamber water was flushed with ambient seawater, thus determining the incubation period, were preselected in this range. In the present study, readings were taken at 1 min intervals and samples were incubated for $15 \mathrm{~min}$ as this maintained chamber oxygen concentration within $10 \%$ of ambient seawater. Power for the operation of the computer and the various mechanical devices is provided by ' $D$ ' size alkaline and lead acid batteries, respectively, which are housed in the electronics compartment.

Respirometers were deployed onto the study sites by SCUBA divers and at the same time the samples of substrata were collected and transferred directly to the

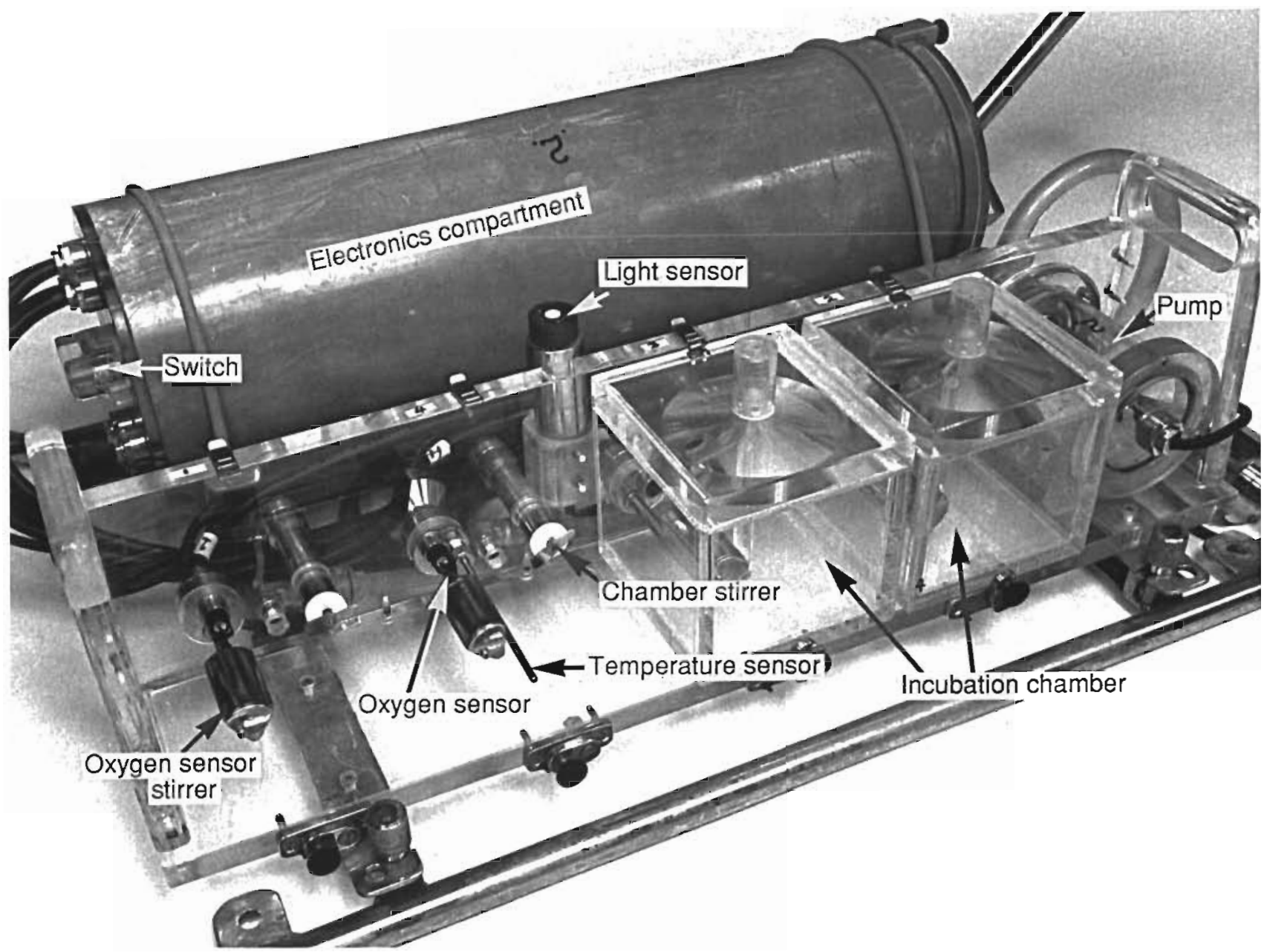

Fig. 2. Data-logging respirometer. Two of the 4 perspex incubation chambers have been removed to display sensors for oxygen and temperature and chamber stirrers 
chambers. The respirometers were deployed for $24 \mathrm{~h}$, then returned to the ship's laboratory to extract data and renew batteries. The respirometers could then be redeployed for installation of a new set of samples. Immediately after each deployment the volume of samples was determined by water displacement, and the samples stored frozen for later analysis of surface area and algal biomass. Surface area of the Acropora sp. branches was calculated using caliper-measured dimensions and geometry, whereas the upper surface and sides of the coral blocks were first photocopied and the areas measured on a digitizer. Algal biomass was determined by drying coral rock samples at $60^{\circ} \mathrm{C}$ and scraping the surface to a depth of $2 \mathrm{~mm}$. This was sufficient to remove the algae from the underlying white coral skeleton. Scrapings were ground in a Wiley mill, redried then analysed for total organic carbon (Sandstrom et al. 1986)

Rates of photosynthesis (P) and respiration (R) over successive 15 min intervals for the total $24 \mathrm{~h}$ deployment period were estimated by linear regression, then plotted against the average irradiance (I) for that period. The model best describing the relation between net photosynthesis and irradiance was found by nonlinear, least-squares regression analysis to be a hyperbolic tangent function, $\mathrm{P}=\mathrm{Pg}_{\max } \tanh \left(\mathrm{I} / \mathrm{I}_{\mathrm{k}}\right)+\mathrm{R}$, where $\mathrm{P} \mathrm{gmax}_{\max }$ is the maximum or asymptotic gross photosynthetic rate, and $I_{k}$ is the irradiance at which the initial slope of the curve, alpha $\left(=\mathrm{Pg}_{\max } / \mathrm{I}_{\mathrm{k}}\right)$, crosses the asymptote. This model has been used to describe the response of photosynthesis to irradiance in a variety of algae (see Chalker et al. 1983 for details). Another important descriptive parameter is $l_{\text {comp, }}$ the irradiance at which oxygen consumption balances production. Total daily oxygen consumption (respiration) and the gross and net production of oxygen were calculated as the sum of actual cumulative oxygen flux during each $15 \mathrm{~min}$ incubation period. Oxygen flux was expressed in terms of surface area of the substratum and its algal biomass (expressed as total organic carbon). Oxygen was converted to carbon equivalents assuming $P Q=R Q=1$; thus $1 \mathrm{mg}$ oxygen equals $0.375 \mathrm{mg}$ carbon. The MannWhitney Text (BMDP3S) was used to test for significance of difference between sample means.

Survey of algal community distribution. Four major substratum categories (fish territories with dense mats of turf algae; closely-cropped filamentous and encrusting coralline algae; bare sand; organisms other than algae) were surveyed during May 1986 across 3 sections of Davies Reef (northern, central and southern section lines are drawn in Fig. 1). Up to 14 sites were established along each of these sections; the locations of sites (with site numbers) were: front reef slope at (\#1) $10 \mathrm{~m}$, and (\#2) $5 \mathrm{~m}$ depths; (\#3) reef crest; reef flat at (\#4) 20, (\#5) 60, (\#6) 80, (\#7) 110 and (\#8) $145 \mathrm{~m}$ behind the crest; (\#9) reef flat at lagoon edge (190 m from the crest); lagoon slope at (\#10) $5 \mathrm{~m}$ and (\#11) $10 \mathrm{~m}$ depths; (\#12) back reef flat; and back reef slope at (\#13) $5 \mathrm{~m}$ and (\#14) $10 \mathrm{~m}$ depths. At each of these sites, a $100 \mathrm{~m}$ tape transect was surveyed perpendicular to the section lines, by recording the length of intercept to the nearest $1 \mathrm{~cm}$ for each major substratum category. Full details on the survey methods and data processing are given in Reichelt et al. (1986).

\section{RESULTS}

\section{Primary productivity inside and outside territories}

Fig. 3 ( $A$ to $C$ ) shows the typical relation between the natural diel pattern in irradiance (Fig. 3D) and net photosynthetic rate for 3 types of algal substratum on the reef flat at Davies Reef during winter: (A) areas outside damselfish territories, (B) areas inside territories of Stegastes apicalis and (C) areas inside territories of $S$. nigricans. In each case the hyperbolic tangent function gave the best fit to the data (coefficient of determination, $\mathrm{r}^{2}=0.97$ to 0.99 ). Oxygen production (photosynthetic rate) tended towards saturation with increasing in situ irradiance which, on this occasion, reached a maximum of $1260 \mu \mathrm{E} \mathrm{m}^{-2} \mathrm{~s}^{-1}$ (Fig. 3D). During April irradiance reached $1500 \mu \mathrm{E} \mathrm{m}^{-2} \mathrm{~s}^{-1}$. Rates of oxygen production change in synchrony with irradiance and there was no evidence of photoinhibition in any of these experiments. The trend towards saturation of oxygen production at high irradiance was more obvious for the algal substrata from outside fish territories.

Table 1a summarizes the parameters of photosynthetic response and rates of primary productivity for algae from outside and inside of damselfish territories under natural diel variations in ambient irradiance. The relation between the algae within each particular damselfish territory and those of the adjacent substratum is presented in Table $1 \mathrm{~b}$ as a ratio together with the level of significant difference (Mann-Whitney Text). The irradiance at which these algal communities approached saturation of oxygen production $\left(l_{k}\right)$ ranged between 331 and $735 \mu \mathrm{E} \mathrm{m}^{-2} \mathrm{~s}^{-1}$. There was no significant difference between $\mathrm{I}_{\mathrm{k}}$ values of damselfish territory and non-territory samples, with the exception of measurements conducted at Davies Reef during August (winter) on substrata associated with Stegastes apicalis and $S$. nigricans. In August the average $I_{k}$ value for areas outside of fish territories was $331 \mu \mathrm{E}$ $m^{-2} s^{-1}(S E=16, n=4)$, significantly lower than for areas occupied by the damselfish $(p=0.02)$. The light compensation point $\left(\mathrm{I}_{\text {comp }}\right)$ varied between 52 and 100 $\mu E \mathrm{~m}^{-2} \mathrm{~s}^{-1}$ depending on location and season. The $\mathrm{I}_{\text {comp }}$ 

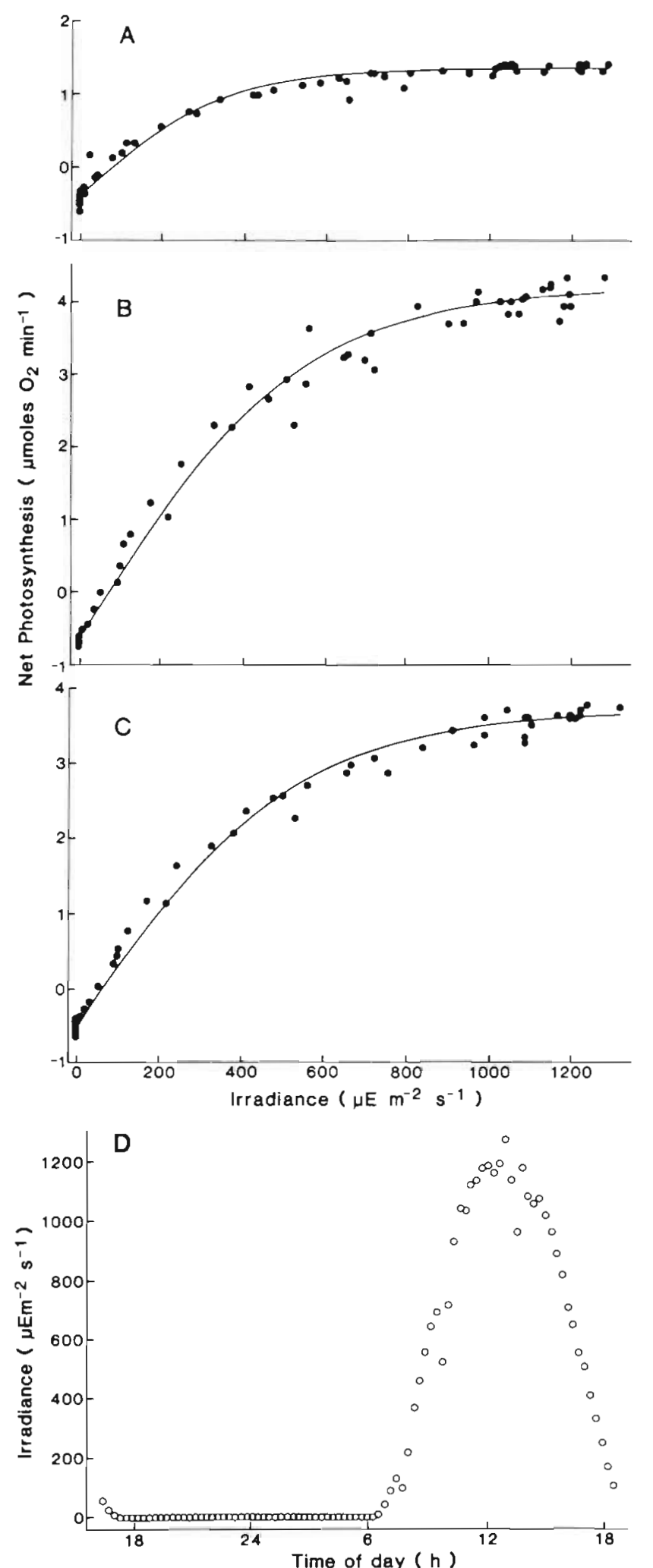

Fig. 3. Representative plots of net oxygen flux versus ambient. irradiance as measured simultaneously for epilithic algal communities from (A) outside fish territories and (B), (C) inside territories of Stegastes apicalis and S. nigricans, respectively Diel pattern of irradiance (D) for the period of these measurements is also shown for fish territory and adjacent algal communities were generally similar. Maximum net photosynthetic rates $\left(\mathrm{P}_{\max }=\mathrm{Pg}_{\max }-\mathrm{R}\right)$, on a substratum surface area basis were in all cases elevated significantly inside fish territories relative to the adjacent substrata. Plectroglyphidodon lacrymatus territories from the Papuan reefs were 1.9 times more active in photosynthetic terms than non-territory epilithic algal communities (EAC). The greatest difference in net photosynthetic rates was found between $S$. nigricans territories $(152 \mu \mathrm{g}$ $\left.\mathrm{O}_{2} \quad \mathrm{~cm}^{-2} \mathrm{~h}^{-1}\right)$ and adjacent substrata $\left(36 \mu \mathrm{g} \quad \mathrm{O}_{2}\right.$ $\mathrm{cm}^{-2} \mathrm{~h}^{-1}$ ) on Davies Reef during winter. The territories of other species of Stegastes were from 2.4 to 3.2 times more active, photosynthetically, than the substrata surrounding them. The initial slope of the P/I curve, here defined as alpha $\left(=\mathrm{Pg}_{\max } / \mathrm{I}_{\mathrm{k}}\right)$, was in all cases significantly higher for territory compared with nonterritory algae. The recorded range for alpha was 0.20 to $0.94 \mu \mathrm{g} \mathrm{O} \mathrm{O}_{2} \mu \mathrm{E}^{-1}$. Respiration rates were, to a lesser extent, significantly higher inside fish territories compared to adjoining areas, except for those of $S$. fasciolatus where rates were equivalent.

Total diel production of oxygen (Pg), expressed in carbon equivalents ( $\mu \mathrm{g}$ oxygen $\times 0.375$ ), by algae inside fish territories was significantly higher on a substratum surface area basis than that produced outside fish territories (Table 1a). The differences were approximately a factor of 2 for Stegastes apicalis in August, S. fasciolatus and Plectroglyphidodon lacrymatus (Table $1 \mathrm{~b}$ ). Surfaces from inside the territories of S. apicalis (in April) and S. nigricans were about 3 times more productive on a surface area basis than adjacent areas. Diel net productivity, $\mathrm{Pn}(=\mathrm{Pg}-\mathrm{R})$, normalized to surface area, of the substrata inside all damselfish territories examined was significantly higher than that of neighbouring algal substrata. The productivity of fish territory substrata was lowest inside areas inhabited by $P$. lacrymatus $\left(1.027 \mathrm{gC} \mathrm{m}^{-2} \mathrm{~d}^{-1}\right)$ and highest where $S$. apicalis $\left(4.332 \mathrm{gC} \mathrm{m}^{-2} \mathrm{~d}^{-1}\right)$ and $S$. nigricans $\left(3.259 \mathrm{gC} \mathrm{m}^{-2} \mathrm{~d}^{-1}\right)$ occurred. Substrata adjacent to fish territories ranged in productivity from $0.480 \mathrm{gC} \mathrm{m}^{-2} \mathrm{~d}^{-1}$ in August on Myrmidon Reef to $1.257 \mathrm{gC} \mathrm{m}^{-2} \mathrm{~d}^{-1}$ on Davies Reef during April.

Relative to biomass of algae, net productivity or turnover (Pnb) of algal communities within all fish territories was significantly higher $(p<0.01)$ than that of the adjacent substrata (Table $1 \mathrm{a}, \mathrm{b}$ ). For example, the territories of Stegastes apicalis on Davies Reef, examined during April, had 1.9 times the biomass of algae per unit of surface area $\left(54.3 \mathrm{gC} \mathrm{m}^{-2}\right)$ of the adjacent algal substratum $\left(29.2 \mathrm{gC} \mathrm{m}^{-2}\right)$. Since this particular fish territory algal community was 3.4 times more productive per unit substratum surface area compared with area outside the territory it follows that these territories were 1.8 times more productive on a 
Table 1 (a). Summary of data comparing the metabolism of epilithic algae from inside and adjacent to damselfish territories: parameters of the photosynthesis-irradiance relation $\left(I_{k}, I_{c o m p} \text { and } \alpha\right)_{i}$ rates of photosynthesis $\left(P_{\max }\right)$ and respiration $(R)_{i}$ primary productivity expressed as the areal gross (Pg) and net (Pna) rates and as the net turnover (Pnb) of community biomass (B). Data are means with standard error in brackets

\begin{tabular}{|c|c|c|c|c|c|c|c|c|c|c|}
\hline $\begin{array}{l}\text { Sample } \\
\text { description }\end{array}$ & \multicolumn{2}{|c|}{$\left(\mu E m^{-2} s^{-1}\right)$} & $\begin{array}{c}\alpha \\
\left(\mu \mathrm{gO}_{2} \mu \mathrm{E}^{-1}\right)\end{array}$ & \multicolumn{2}{|c|}{$\left(\mu \mathrm{gO}_{2} \mathrm{~cm}^{-2} \mathrm{~h}^{-2}\right)$} & \multicolumn{2}{|c|}{$\left(g C m^{-2} d^{-1}\right)$} & $\begin{array}{c}P n b \\
\left(\% d^{-1}\right)\end{array}$ & $\begin{array}{c}\mathrm{B} \\
\left(\mathrm{g} \mathrm{Cm}^{-2}\right)\end{array}$ & n \\
\hline \multicolumn{11}{|l|}{ Davies Reef (GBR) } \\
\hline April & $\begin{array}{l}612 \\
(52)\end{array}$ & $\begin{array}{c}100 \\
(6)\end{array}$ & $\begin{array}{l}0.35 \\
(0.06)\end{array}$ & $\begin{array}{l}78 \\
(6)\end{array}$ & $\begin{array}{l}13.5 \\
(1.3)\end{array}$ & $\begin{array}{c}2.480 \\
(0.187)\end{array}$ & $\begin{array}{l}1.257 \\
(0.119)\end{array}$ & $\begin{array}{l}4.6 \\
(0.67)\end{array}$ & $\begin{array}{l}29.2 \\
(2.5)\end{array}$ & 8 \\
\hline August & $\begin{array}{l}331 \\
(16)\end{array}$ & $\begin{array}{l}77 \\
(3)\end{array}$ & $\begin{array}{c}0.30 \\
(0.04)\end{array}$ & $\begin{array}{l}36 \\
(4)\end{array}$ & $\begin{array}{l}9.7 \\
(0.6)\end{array}$ & $\begin{array}{c}1.528 \\
(0.173)\end{array}$ & $\begin{array}{c}0.805 \\
(0.084)\end{array}$ & $\begin{array}{c}2.4 \\
(1.25)\end{array}$ & $\begin{array}{l}32.5 \\
(1.5)\end{array}$ & 4 \\
\hline \multicolumn{11}{|l|}{$\begin{array}{l}\text { Inside territories of } \\
\text { Stegastes apicalis }\end{array}$} \\
\hline April & $\begin{array}{l}735 \\
(56)\end{array}$ & $\begin{array}{l}86 \\
(3)\end{array}$ & $\begin{array}{c}0.94 \\
(0.11)\end{array}$ & $\begin{array}{l}249 \\
(23)\end{array}$ & $\begin{array}{l}28.5 \\
(1.7)\end{array}$ & $\begin{array}{c}7.003 \\
(0.524)\end{array}$ & $\begin{array}{c}4.332 \\
(0.417)\end{array}$ & $\begin{array}{c}8.2 \\
(0.8)\end{array}$ & $\begin{array}{l}54.3 \\
(5.4)\end{array}$ & 8 \\
\hline August & $\begin{array}{l}514 \\
(10)\end{array}$ & $\begin{array}{l}83 \\
(3)\end{array}$ & $\begin{array}{c}0.52 \\
(0.04)\end{array}$ & $\begin{array}{l}98 \\
(7)\end{array}$ & $\begin{array}{l}16.7 \\
(0.7)\end{array}$ & $\begin{array}{c}3.368 \\
(0.237)\end{array}$ & $\begin{array}{c}1.849 \\
(0.178)\end{array}$ & $\begin{array}{l}4.0 \\
(0.7)\end{array}$ & $\begin{array}{l}47.7 \\
(3.2)\end{array}$ & 4 \\
\hline \multicolumn{11}{|l|}{ Stegastes nigricans } \\
\hline August & $\begin{array}{l}501 \\
(14)\end{array}$ & $\begin{array}{l}60 \\
(3)\end{array}$ & $\begin{array}{c}0.84 \\
(0.05)\end{array}$ & $\begin{array}{l}152 \\
(13)\end{array}$ & $\begin{array}{l}17.7 \\
(1.5)\end{array}$ & $\begin{array}{c}4.902 \\
(0.258)\end{array}$ & $\begin{array}{l}3.259 \\
(0.155)\end{array}$ & $\begin{array}{l}8.2 \\
(0.7)\end{array}$ & $\begin{array}{l}40.6 \\
(2.6)\end{array}$ & 4 \\
\hline \multicolumn{11}{|l|}{ Myrmidon Reef (GBR) } \\
\hline August & $\begin{array}{l}337 \\
(52)\end{array}$ & $\begin{array}{c}65 \\
\{11\}\end{array}$ & $\begin{array}{c}0.20 \\
(0.03)\end{array}$ & $\begin{array}{l}24 \\
(2)\end{array}$ & $\begin{array}{c}5.4 \\
(0.2)\end{array}$ & $\begin{array}{c}0.997 \\
(0.082)\end{array}$ & $\begin{array}{c}0.480 \\
(0.070)\end{array}$ & $\begin{array}{c}2.3 \\
(0.6)\end{array}$ & $\begin{array}{l}20.8 \\
(3.4)\end{array}$ & 6 \\
\hline $\begin{array}{l}\text { Inside territories of } \\
\text { Stegastes fasciolatus }\end{array}$ & $\begin{array}{l}428 \\
(45)\end{array}$ & $\begin{array}{l}70 \\
(6)\end{array}$ & $\begin{array}{c}0.37 \\
(0.03)\end{array}$ & $\begin{array}{l}57 \\
(8)\end{array}$ & $\begin{array}{c}9.0 \\
(0.9)\end{array}$ & $\begin{array}{c}1.833 \\
(0.200)\end{array}$ & $\begin{array}{c}1.252 \\
(0.113)\end{array}$ & $\begin{array}{l}5.2 \\
(1.4)\end{array}$ & $\begin{array}{l}24.0 \\
(4.4)\end{array}$ & 6 \\
\hline \multicolumn{11}{|c|}{ Motupore Island (PNG) } \\
\hline September & $\begin{array}{r}366 \\
(1)\end{array}$ & $\begin{array}{l}59 \\
(2)\end{array}$ & $\begin{array}{c}0.30 \\
(0.04)\end{array}$ & $\begin{array}{l}40 \\
(1)\end{array}$ & $\begin{array}{c}8.2 \\
(0.2)\end{array}$ & $\begin{array}{c}1.374 \\
(0.094)\end{array}$ & $\begin{array}{c}0.648 \\
(0.007)\end{array}$ & $\begin{array}{c}6.7 \\
(0.4)\end{array}$ & $\begin{array}{l}9.7 \\
(0.4)\end{array}$ & 8 \\
\hline $\begin{array}{l}\text { Inside territories of } \\
\text { Plectroglyphididon } \\
\text { lacrymatus }\end{array}$ & $\begin{array}{l}374 \\
(17)\end{array}$ & $\begin{array}{l}52 \\
(2)\end{array}$ & $\begin{array}{c}0.57 \\
(0.05)\end{array}$ & $\begin{array}{l}77 \\
(6)\end{array}$ & $\begin{array}{l}10.6 \\
(0.7)\end{array}$ & $\begin{array}{c}2.456 \\
(0.195)\end{array}$ & $\begin{array}{l}1.027 \\
(0.042)\end{array}$ & $\begin{array}{c}9.9 \\
(1.3)\end{array}$ & $\begin{array}{l}14.6 \\
(0.9)\end{array}$ & 12 \\
\hline
\end{tabular}

Table 1(b). Comparison of algae from damselfj.sh territories with those of equivalent adjacent substrata expressed as the ratio of parameters from Table $1 a$, with the level of significant differences ( $p$ ) as determined by Mann Whitney Test

\begin{tabular}{|c|c|c|c|c|c|c|c|c|c|}
\hline Species & $I_{k}$ & $I_{\text {comp }}$ & $\alpha$ & $P_{\text {max }}$ & $\mathrm{R}$ & $\mathrm{Pg}$ & Pna & Pnb & B \\
\hline \multicolumn{10}{|l|}{ Stegastes apicalis } \\
\hline Apri. & NS & NS & $\begin{array}{c}2.5 \\
(<0.001)\end{array}$ & $\begin{array}{c}3.2 \\
(<0.001)\end{array}$ & $\begin{array}{c}2.1 \\
(<0.001)\end{array}$ & $\begin{array}{c}2.8 \\
(<0.001)\end{array}$ & $\begin{array}{c}3.4 \\
\{<0.001)\end{array}$ & $\begin{array}{l}1.8 \\
(0.01)\end{array}$ & $\begin{array}{l}1.9 \\
(0.002)\end{array}$ \\
\hline August & $\begin{array}{l}1.5 \\
(0.02)\end{array}$ & NS & $\begin{array}{l}1.8 \\
(0.01)\end{array}$ & $\begin{array}{l}2.7 \\
(0.02)\end{array}$ & $\begin{array}{l}1.7 \\
(0.03)\end{array}$ & $\begin{array}{l}2.2 \\
(0.02)\end{array}$ & $\begin{array}{l}2.3 \\
(0.02)\end{array}$ & $\begin{array}{l}1.7 \\
(0.01)\end{array}$ & $\begin{array}{l}1.5 \\
(0.01)\end{array}$ \\
\hline S. nigricans & $\begin{array}{l}1.5 \\
(0.02)\end{array}$ & $\begin{array}{l}0.8 \\
(0.02)\end{array}$ & $\begin{array}{l}2.8 \\
(0.01)\end{array}$ & $\begin{array}{l}4.2 \\
(0.02)\end{array}$ & $\begin{array}{l}1.8 \\
(0.02)\end{array}$ & $\begin{array}{l}3.2 \\
(0.02)\end{array}$ & $\begin{array}{l}4.0 \\
(0.02)\end{array}$ & $\begin{array}{l}3.4 \\
(0.01)\end{array}$ & $\begin{array}{l}1.2 \\
(0.01)\end{array}$ \\
\hline S. fasciolatus & NS & $\begin{array}{l}1.1 \\
(0.03)\end{array}$ & $\begin{array}{l}1.9 \\
(0.01)\end{array}$ & $\begin{array}{l}2.4 \\
(0.002)\end{array}$ & NS & $\begin{array}{l}1.8 \\
(0.002)\end{array}$ & $\begin{array}{c}2.1 \\
(<0.001)\end{array}$ & $\begin{array}{c}2.3 \\
(0.01)\end{array}$ & NS \\
\hline $\begin{array}{l}\text { Plectroglyphididon } \\
\text { lacrymatus }\end{array}$ & NS & NS & $\begin{array}{c}1.9 \\
(0.01)\end{array}$ & $\begin{array}{l}1.9 \\
(0.004)\end{array}$ & $\begin{array}{l}1.3 \\
(0.004)\end{array}$ & $\begin{array}{l}1.8 \\
(0.004)\end{array}$ & $\begin{array}{l}1.6 \\
(0.006)\end{array}$ & $\begin{array}{l}1.5 \\
(0.01)\end{array}$ & $\begin{array}{l}1.5 \\
(0.01)\end{array}$ \\
\hline
\end{tabular}


Table 2. Physiological parameters of oxygen flux from epilithic algae on open grazed surfaces (uncaged) compared with caged treatments. See Table la for explanation of terms. Readings taken in May on Davies Reef. Data are means (standard deviation)

\begin{tabular}{|c|c|c|c|c|c|c|c|c|c|c|}
\hline Sample & $\begin{array}{l}\mathrm{I}_{\mathrm{k}} \\
(\mu \mathrm{E}\end{array}$ & $\begin{array}{l}I_{\text {comp }} \\
\left.s^{-1}\right)\end{array}$ & $\left(\mathrm{P}_{\text {malx }}^{\alpha} / \mathrm{I}_{\mathrm{k}}\right)$ & $\begin{array}{c}P_{\max } \\
\left(\mu \mathrm{O}_{2}\right.\end{array}$ & $\begin{array}{c}\mathrm{R} \\
\left.{ }^{2} \mathrm{~h}^{-1}\right)\end{array}$ & $\mathrm{Pg} / \mathrm{R}$ & $\begin{array}{c}\operatorname{Pn} \\
\left(g C m^{-2} d^{-1}\right)\end{array}$ & $\begin{array}{c}\operatorname{Pn} \\
\left(\% d^{-1}\right)\end{array}$ & $\begin{array}{c}\mathrm{B} \\
\left(\mathrm{gC} \mathrm{m}^{-2}\right)\end{array}$ & $\mathrm{N}$ \\
\hline $\begin{array}{l}\text { Uncaged } \\
\text { Substrata }\end{array}$ & $\begin{array}{l}395 \\
(81)\end{array}$ & $\begin{array}{c}57 \\
(12)\end{array}$ & $\begin{array}{c}0.44 \\
(0.05)\end{array}$ & $\begin{array}{l}62.9 \\
(7.6)\end{array}$ & $\begin{array}{c}8.7 \\
(1.5)\end{array}$ & $\begin{array}{l}2.4 \\
(0.1)\end{array}$ & $\begin{array}{c}1.134 \\
(0.177)\end{array}$ & $\begin{array}{c}4.9 \\
(1.2)\end{array}$ & $\begin{array}{l}22.9 \\
(3.5)\end{array}$ & 7 \\
\hline Caged & $\begin{array}{l}411 \\
(33)\end{array}$ & $\begin{array}{l}53 \\
(7)\end{array}$ & $\begin{array}{c}0.62 \\
(0.05)\end{array}$ & $\begin{array}{c}91.8 \\
(42.7)\end{array}$ & $\begin{array}{l}11.1 \\
(3.9)\end{array}$ & $\begin{array}{c}2.7 \\
(0.4)\end{array}$ & $\begin{array}{c}1.837 \\
(0.991)\end{array}$ & $\begin{array}{c}4.9 \\
(2.2)\end{array}$ & $\begin{array}{l}36.2 \\
(4.3)\end{array}$ & 8 \\
\hline
\end{tabular}

biomass basis. Similarly, the productivity per unit biomass of $S$. apicalis territories during winter was 1.7 times that of the adjacent substratum. The algae from the territories of other species of damselfish examined in this study were from 1.5 to 3.4 times more productive than the algae surrounding each territory. The biomass of algae in these cases was again higher inside the territories, with the exception of $S$. fasciolatus on Myrmidon Reef, where no significant difference in substratum algal biomass was observed.

Dense mats of algae were created artificially on Davies Reef by caging the openly grazed substratum for a period of $30 \mathrm{~d}$. A comparison of this with the uncaged algal community revealed that the rate of photosynthesis for each type of community was both compensated $\left(\mathrm{I}_{\text {comp }}\right)$ and saturated $\left(\mathrm{I}_{\mathrm{k}}\right)$ at similar levels of irradiance (Table 2). Caging increased algal biomass significantly $(\mathrm{p}=0.001)$ from 22.9 to $36.2 \mathrm{gC} \mathrm{m}^{-2}$. Mean areal productivity of the caged surface was higher $\left(1.837 \mathrm{gC} \mathrm{m}^{-2} \mathrm{~d}^{-1}\right)$ than the uncaged are $(1.134$ gC $\left.\mathrm{m}^{-2} \mathrm{~d}^{-1}\right)$, but not significantly so. Net productivity per unit biomass of algae was identical $\left(4.9 \% \mathrm{~d}^{-1}\right)$ for these 2 types of substrata.

\section{Algal community distribution}

Three sections (north, central and south) across the width of Davies Reef (Fig. 1) were surveyed, each section including transect sites from the reef slope at 10 and $5 \mathrm{~m}$ to the crest and shallow reef flat. Epilithic algal communities, including coralline algae, turf algae (filamentous forms) and algae within fish territories (thick turfs) occupy a high proportion of the substratum of the Reef (Fig. 4). Areas of least algal cover (25 to $40 \%$ ) were usually on the front reef slopes (Sites 1 and 2) where there was a higher proportion of live coral cover. Coralline algae and corallines mixed with short turf were the dominant algae on these slopes. Back reef slopes (Sites 13 and 14) had a higher algal cover (60 to $70 \%$ ) than the front reef areas. Reef flats (Sites 4 to 9 and 12) were the richest zones of epilithic algal cover (including territories of damselfish) with an average of $77 \%$ of the substratum along the central section of the reef being covered with algae. Damselfish territories were a minor component on the reef slopes (Sites 1, 2, $10,11,13$ and 14) but on some parts of the reef flat they predominated. These territories were particularly obvious along the front-reef flat where they occupied a $100 \mathrm{~m}$ wide band behind the crest (Site 3), with an average percentage cover of $42 \%$ over the 3 cross-reef sections. Another area of high relative cover (31\%) by damselfish territories was along the outer edges of the back-reef flat (Site 12). The peak in damselfish territory cover occurred about $25 \mathrm{~m}$ back from the fore-reef crest (Site 4) where the mean cover was $61 \%$ for the 3 sections of reef.

On Davies Reef the predominant species of territorial (herbivorous) damselfish in terms of reef substratum occupied was Stegastes apicalis. The front- and backreef damselfish territory zones (at Sites 3 to 5, 9 and 12) described above were almost entirely occupied by this species. S. nigricans tended to occur among Acropora $\mathrm{sp}$. thickets in the more sheltered parts of the mid-reef flat (Sites 7 and 8). S. apicalis was also found in this area. The equivalent dominant to $S$. apicalis on the Motupore Island fringing reefs was Plectroglyphidodon lacrymatus, which occupied a large proportion of the coral rock substrata on the outermost reef flat and upper reef slope (N.V. Polunin pers. comm.), extending down to over $7 \mathrm{~m}$ depth. This species had less extensive territorial coverage on the GBR reefs examined, being confined more to the reef slopes just below $S$. apicalis. The reef flat at Myrmidon Reef was most extensively colonized by $S$. fasciolatus.

\section{DISCUSSION}

Here, we will compare briefly our preliminary results on the primary productivity and photosyntheticirradiance relationships of Great Barrier Reef epilithic algal communities with the little published data available. Borowitzka et al. (1978) measured the productivity of algal turf communities grown on glass slides at One Tree Island (GBR) using the ${ }^{14} \mathrm{C}$ technique. Only Wanders (1976) and Carpenter (1985) have presented data on photosynthetic rates of coral reef epilithic algae 


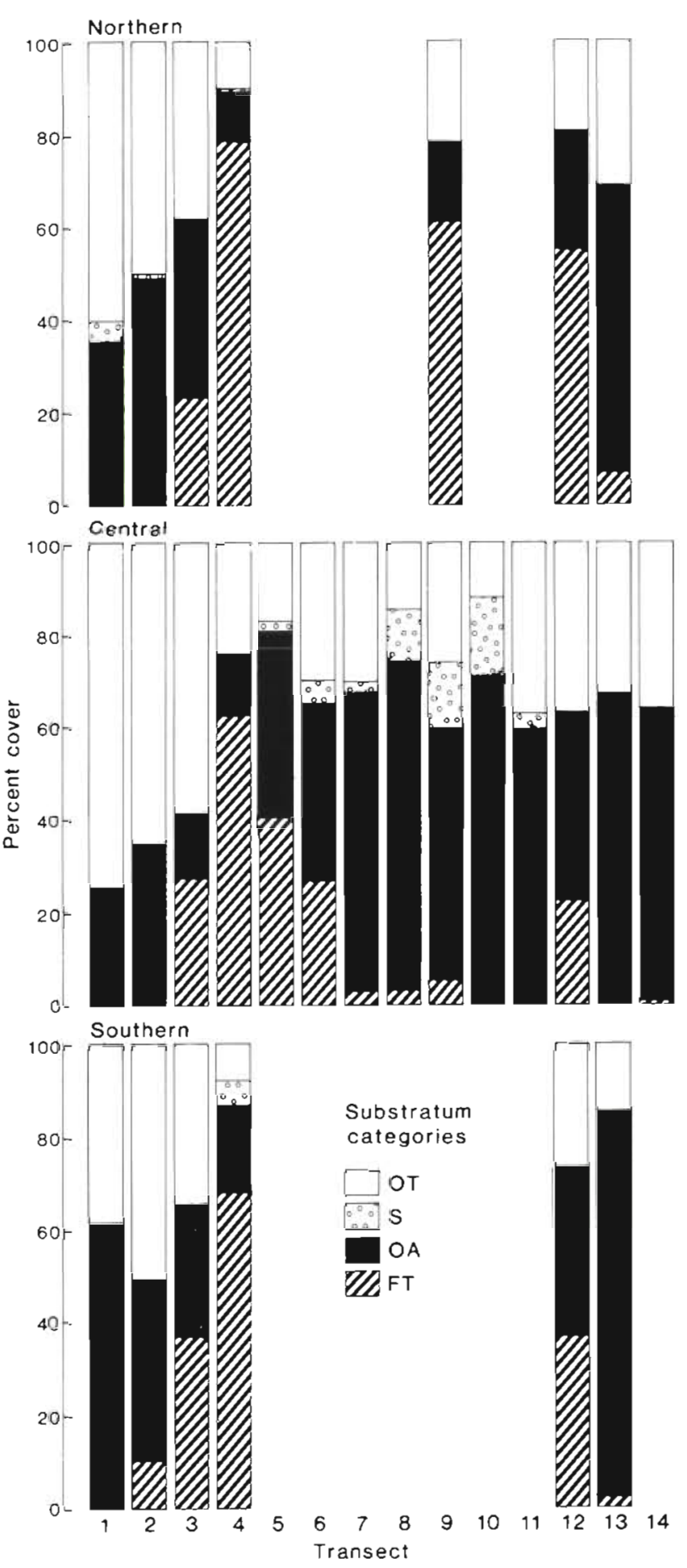

Fig. 4. Changes in relative compositional cover of substratum (FT: fish territory; OA: coralline algae and short turf algae; $\mathrm{S}$ sand; OT: other) at 14 transect sites across the northern central and southern sections of Davies Reef. Transect site locations (in numerical order from front to back reef) are described in 'Materials and Methods'

on natural substrata, measured using the oxygen technique. Vooren (1981) reported on the benthic algae of deep coral reefs. These authors carried out their studies in the Caribbean while the present study is the first of this type for epilithic algae of the Great Barrier Reef region. Wanders (1976) measured photosynthesis and respiration, using short incubation light/dark bottles, of the separate major species of reef algae, whereas Carpenter (1985), who did not differentiate between algal taxa or substratum type, examined algal communities colonizing coral plates, using in situ, automated measurement techniques similar to those of the present study. In all cases the analysis of photosynthetic response of these algae to irradiance (see Fig. 3) demonstrated a symmetrical pattern with ascending and descending natural light levels, i.e. no photoinhibition was evident. Most parameters of the hyperbolic tangent functions (alpha, $\mathrm{I}_{\text {comp }}$ R and $\mathrm{P}_{\max }$ ) reported by Carpenter (1985) compare closely with our data, particularly for our non-territory algae. In both studies, these algae were found to be relatively inefficient photosynthetically (alpha approximately $0.3 \mu \mathrm{g} \quad \mathrm{O}_{2}$ $\left.\mu \mathrm{E}^{-1}\right)$. The compensation light intensity, $\mathrm{I}_{\text {comp, }}$ varied similarly between 50 and $100 \mu \mathrm{E} \mathrm{m}^{-2} \mathrm{~s}^{-1}$. Respiration rates reported here were identical to those found by Wanders (1976) and Carpenter (1985). Maximum net photosynthetic rates ranged between 70 and $100 \mu \mathrm{O} \mathrm{O}_{2}$ $\mathrm{cm}^{-2} \mathrm{~h}^{-1}$ according to Carpenter, somewhat higher than either Wander's data (15 to 34 for corallines and sparse turfs) or ours for non-territory substrata (24 to 78). Wanders distinguishes a 'dense' turf algae $\left(\mathrm{P}_{\max }=\right.$ 64), which we assume can be equated, in terms of biomass, with the fish territory-type algae of the present study ( $P_{\max }=57$ to 249$)$. From our preliminary data it appears that $P_{\max }$ is approached at a lower irradiance in Great Barrier Reef algae $\left(I_{k}=337\right.$ to $\left.735 \mu \mathrm{E} \mathrm{m}^{-2} \mathrm{~s}^{-1}\right)$ compared with that of Caribbean algae $\left(\mathrm{I}_{\mathrm{k}}=742\right.$ to $1184 \mu \mathrm{E} \mathrm{m}^{-2} \mathrm{~s}^{-1}$ in Carpenter 1985).

Carpenter (1985) calculated the net primary productivity of the algae colonizing his coral plates to be between 2.1 and $3.1 \mathrm{gC} \mathrm{m}^{-2} \mathrm{~d}^{-1}$, which is in the range reported here, if fish territory algal substrata are included ( $u p$ to $4.3 \mathrm{gC} \mathrm{m}^{-2} \mathrm{~d}^{-1}$ ). The biomass of Caribbean algae examined by Carpenter was 5.5 to $11 \mathrm{gC}$ $\mathrm{m}^{-2}$ compared with 20 to $32 \mathrm{gC} \mathrm{m}^{-2}$ for the non-territory algae of Davies and Myrmidon reefs. The primary productivity of these particular Great Barrier Reef algae was 0.8 to 1.3 and $0.5 \mathrm{gC} \mathrm{m}^{-2} \mathrm{~d}^{-1}$, respectively. Thus the turnover of these algae was about an order of magnitude less than those on Caribbean substrata at equivalent seasons. Inclusion of the high-production high-biomass fish territory substrata in the comparison halves this difference. Coral plates colonized by algae on Davies Reef and incubated in May (Table 2) were, again, less productive on a surface area (1/2) or biomass ( ) ) basis than the Caribbean algae grown on similar substrata and monitored at an equivalent season (November) by Carpenter (1985). Further investigation 
comparing equivalent substrata is needed to verify these apparent differences in the biomass and productivity of coral reef epilithic algal communities of Caribbean and Pacific waters.

Only Montgomery (1980) has reported on the oxygen production of algae inside and adjacent to the territories of a herbivorous damselfish, Microspathodon dorsalis, on a granite boulder reef in the Gulf of California. This fish occupied territories dominated by Polysiphonia sp. which, in contrast to our situation, had 13 to 26 times less biomass than the surrounding algal mat. Instantaneous measurements of oxygen production, which were not considered by that author to be an accurate estimate of true productivity in his case, showed that, relative to the surrounding algal mats, the territories were, as in the case of coral reefs studied by us, 2.5 times more productive on a surface area basis. However, the differential between $M$. dorsalis territories and the adjacent areas was far greater (34 to 47 times), when standardized to biomass, than observed for coral reef areas (Table $1 \mathrm{~b}$ ). Russ (in press) used the increment in algal biomass on coral plates following a period of grazer exclusion by caging as a measure of algal production at Myrmidon Reef. This method could be criticized on the grounds that it assumes the greatly increased algal density following caging does not eventually affect production. However, our results comparing photosynthetic rates of caged with uncaged plates (identical treatment to that of Russ) showed that caging under these circumstances does not affect productivity of the algal tissue. Russ reported the productivity of algal tissue on open grazed surfaces of Myrmidon during mid-summer to be $0.69 \mathrm{gC} \mathrm{m}^{-2} \mathrm{~d}^{-1}$ compared with $1.20 \mathrm{gC} \mathrm{m}^{-2} \mathrm{~d}^{-1}$ inside territories of Stegastes fasciolatus. This is practically identical to our results for this reef in spring (0.480 and $1.252 \mathrm{gC} \mathrm{m}^{-2} \mathrm{~d}^{-1}$, respectively).

Our survey of substratum composition on Davies Reef demonstrated that epilithic algae cover a large proportion of the reef. These algal communities are the major contributer to primary productivity of coral reefs (Smith \& Marsh 1973, Marsh 1976a, Wanders 1976 , Rogers \& Salesky 1981, Carpenter 1985) and a high proportion of this production is directly available to the food chain (see reviews by Hatcher 1983 and Hixon 1983). We have demonstrated that herbivorous damselfish territories, by the nature of their high productivity and extensive cover of the reef substratum, must exert a strong influence on this production. Sammarco \& Williams (1982) found that over $50 \%$ of the reef flat on Jamaican back reefs was covered with ternitories of Eupomacentrus planifrons. The 4 species of damselfish examined by us each occupied territories covering a similarly high proportion of the reef flat (approximately $40 \%$ for Stegastes apicalis) and in which the areal primary productivity was significantly enhanced (2 to 4 times) over that of the surrounding substratum.

Damselfish have been studied in detail with respect to the influence they have on algal community biomass and structure within their territories. For example, it is well documented that such territories are zones of relatively enriched algal biomass (Vine 1974, Brawley \& Adey 1977, Lassuy 1980, Williams 1981, Russ in press), and our results in general confirm this. However, high biomass density alone does not account for the enhanced rates of primary production per surface area recorded inside fish territories compared with that of the surrounding substratum. We have shown that damselfish territories in several different habitats have algal communities which are 2 to 3 times more productive, relative to the total community biomass, than the algal communities on substrata surrounding these territories. At least 3 explanations can be suggested to explain why damselfish territories are so productive relative to their surroundings: (1) 'weeding' activities of the damselfish promote more highly productive algal species or forms; (2) cropping action of the damselfish, as opposed to other fish grazers, keeps algae in an exponential phase of growth; and (3) the damselfish wastes 'fertilize' the algae.

Damselfish territories are characterized by filamentous algae (turfs), red and blue-green algae in particular (Lassuy 1980, Lobel 1980, Sammarco 1983, Scott \& Russ 1987, Klumpp \& Polunin unpubl, data), but encrusting corallines, which dominate the substratum outside of territories, are a minor component. Measurements of the photosynthetic rates of individual species in the epilithic algal communities on coral reefs (Marsh 1976b, Wanders 1976, Vooren 1981) indicate that algal turfs (apparently non-territorial in origin) are about 5 times more productive per surface area than corallines. Vooren (1981) also states that dense turfs are about twice as productive per unit biomass as corallines. In the investigation of enhanced production within damselfish territories it would be informative to compare the productive capacity of dense turfs from within and outside territories. Our experiments with caged substrata (Table 2) indicate that the preponderance of inherently productive turf algae inside territories as an explanation for high productivity of these areas is not complete. Caged substrata developed thick algal turfs in the absence of grazing with similar general composition to territorial zones. The productivity of these artificially created thick turfs increased directly with the rise in biomass and was, therefore, no greater than the unmanipulated surfaces on a unit biomass basis.

The damselfish in this study all fed predominantly upon the algae within their territories (Lobel 1980, Robertson \& Polunin 1981, Klumpp \& Polunin unpubl. data). Another explanation for high territory algal pro- 
duction is that the damselfish by such feeding are maintaining the algal filaments in an exponential phase of growth, whereas the activities of the abundant grazers (mainly acanthurids, scarids and siganids) feeding on the areas outside do not have the same effect. Studies in the Caribbean (Williams 1981) and recent research by Russ (in press) on Stegastes fasciolatus at Myrmidon Reef have shown that grazing rate inside territories is at least as high as the adjacent substratum. Although the rate at which algae are cropped appears to be equivalent in both habitats, the modes of feeding inside territories ensures that algal filaments persist in contrast to the grazed-down 'pavements' which characterize open surfaces. Thus fine filaments among these pavements may be maintained at a less than optimum rate of growth.

Aggregations of diumally-migrating fish on coral reefs have been shown to locally enhance ambient concentrations of nutrients (nitrogen and phosphorus) through excretion and defaecation and there appears to be good evidence that this stimulates coral growth in the vicinity of such aggregations (Meyer et al. 1983, Meyer \& Schultz 1985a, b). Polunin (in press) demonstrated that the damselfish Plectroglyphidodon lacrymatus on Motupore Island reefs can have a similar localized effect on nutrient concentrations within their territories. Efficient recycling by territorial damselfish of nutrients such as nitrogen and phosphorus and the release of these in close proximity to the zone of algal production may, in turn, enhance productivity above that of more 'nutritionally diffuse' surroundings

Acknowledgements. We acknowledge the enthusiastic support of the staff of AIMS in several facets of this study. Firstly we thank Dr Ed Drew and Monty Devereux for advice on design, and G. McNaughton for the construction, of our prototype respirometer. We are especially grateful to the following staff who assisted with development and construction of the final versions of the instrument: $M$. Beecher, J. Collingwood, E. Gill, D. Donohoe, J. Small and H. Le-Donne. Dr B. Chalker and Mr J. Clay helped with logger programming. For assistance in the field we thank the captain and crew of R. V Harry Messel, the staff of Motupore Island Research Station (P.N.G.), and Mr P. Speare. Drs E. Drew, P. Sammarco, A. Dartnall and N.V Polunin, and 4 anonymous reviewers provided helpful criticism of the manuscript.

\section{LITERATURE CITED}

Borowitzka, M. A., Larkum, A. W. D., Borowitzka, L. J. (1978). A preliminary study of algal turf communities of a shallow coral reef lagoon using an artificial substratum. Aquat. Bot. 5: $365-381$

Brawley, S. H., Adey, W H. (1977). Territorial behavior of threespot damselfish (Eupomacentrus planifrons) increases reef algal biomass and productivity. Environ. Biol. Fish. 2: 45-51
Carpenter, R. C. (1981). Grazing by Diadema antillarum and its effects on the benthic algal community. J. mar. Res. 39 : $749-765$

Carpenter, R. C. (1985). Relationships between primary production and irradiance in coral reef algal communities. Limnol. Oceanogr. 30: 784--793

Carpenter, R. C. (1986). Partitioning herbivory and its effects on coral reef algal communities. Ecol. Monogr. 56: 345-363

Chalker, B. E., Dunlap, W. C., Oliver, J. K. (1983). Bathymetric adaptations of reef-building corals at Davies Reef, Great Barnier Reef, Australia. II. Light saturation curves for photosynthesis and respiration. J. exp. mar. Biol. Ecol. 73: $37-56$

Hatcher, B. G. (1982). The interaction between grazing organisms and the epilithic algal community of a coral reef: a quantitative assessment. Proceedings 4th International Coral Reef Symposium, Manila, Vol. 2: 515-524

Hatcher, B. G. (1983). Grazing in coral reef ecosystems. In: Barnes, D. J. (ed.) Perspectives on coral reefs. Proceedings of Workshop, Aug 1979, Aust. Inst. Mar. Sci., Townsville. B. Clouston, Manuka, A.C.T., p. 164-169

Hixon, M. A. (1983). Fish grazing and community structure of reef corals and algae: a synthesis of recent studies. In: Reake, M. L. (ed.) The ecology of deep and shallow coral reefs. Symp. Ser. for Undersea Research, NOAA, Rockville, 1: 79-87

Hixon, M. A., Brostoff, W. N. (1981). Fish grazing and community structure of Hawaiian reef algae. Proceedings 4 th International Coral Reef Symposium, Manila, Vol. 2: 507-514

Hoek, C. van den (1969). Algal vegetation-types along the open coasts of Curaçao. Proc. K. ned. Akad. Wet., Ser. C 72: $537-577$

Kamura, S. Choonhabandit, S. (1986). Algal communities within territories of the damselfish Stegastes apicalis and the effects of grazing by the sea urchin Diadema spp. in the Gulf of Thailand. Galaxea 5: 175-193

Lassuy, D. R. (1980). Effects of 'farming' behavior by Eupomacentrus lividus and Hemiglyphididon plagiometopon on algal community structure. Bull. mar. Sci. 30 304-312

Lobel, P. S. (1980). Herbivory by damselfishes and their role in coral reef community ecology. Bull. mar. Sci. 30:273-289

Marsh, J A. (1976a). Energetic role of algae in reef ecosystems. Micronesica 12: 13-21

Marsh, J. A. (1976b). Primary productivity of reef-building calcareous red algae. Ecology 51: 255-263

Meyer, J. L., Schultz, E. T (1985a). Migrating haemulid fishes as a source of nutrients and organic matter on coral reefs. Limnol. Oceanogr. 30: 146-156

Meyer, J., Schultz, E. T (1985b). Tissue weight and growth rate of corals associated with schooling fish. Limnol. Oceanogr. 30: 157-166

Meyer, J. L., Schultz, E. T., Helfman, G. S. (1983). Fish schools: an asset to corals. Science 220: 1047-1049

Montgomery, W. L. (1980). The impact of non-selective grazing by the giant blue damselfish Microspathodon dorsalis, on algal communities in the Gulf of California, Mexico. Bull. mar. Sci. 47: 9-24

Ogden, J. C., Lobel, P. S. (1978). The role of herbivorous fishes and urchins in coral reef communities. Environ. Biol. Fish 3: $49-63$

Polunin, N. V C. (in press). Temporal focussing of nitrogen release periodically-feeding herbivorous reef fish. J. exp. mar. Biol. Ecol.

Reichelt, R. E., Loya, Y., Bradbury, R. H. (1986). Patterns in the 
use of space in two coral reefs of the Great Barrier Reef. Coral Reefs 5: 73-79

Robertson, D. R., Polunin, N. V (1981). Coexistence: symbiotic sharing of feeding areas and algal food by some coral reef fishes from the western Indian Ocean. Mar Biol. 62: 185-195

Rogers, C. S., Salesky, N. (1981). Productivity of Acropora palmata, macroscopic algae, and algal turfs from Tague Bay reef, St. Croix, U. S. Virgin Islands. J exp. mar. Biol. Ecol. 49: 179-187

Russ, G. (in press). Is grazing reduced inside territories of tropical damselfishes? J. exp. mar Biol. Ecol.

Ruyter van Steveninck, E. D. de (1984). The composition of algal vegetation in and outside damselfish territories on a Florida reef. Aquat. Bot. 20: 11-19

Sammarco, P. W. (1983). Effects of fish grazing and damselfish territoriality on coral reef algae. I. Algal community structure Mar. Ecol. Prog. Ser. 13: 1-14

Sammarco, P. W., Williams, A. H. (1982). Damselfish territoriality: influence of Diadema distribution and implications for coral community structure. Mar. Ecol. Prog. Ser. 8: $53-59$
Sandstrom, M. W., Tirendi, F., Nott, A. (1986). Direct determination of organic carbon in modern reef sediments and calcareous organisms after dissolution of carbonate. Mar Geol. 70: 321-329

Scott, F. J., Russ, G. R. (1987). Effects of grazing on species composition of the epilithic algal community on coral reefs of the central Great Barrier Reef. Mar Ecol. Prog. Ser 39: 293-304

Smith, S. V., Marsh, J. A. (1973). Organic carbon production on the windward reef flat of Eniwetok Atoll. Limnol. Oceanogr. 18: 953-961

Vine, P. J. (1974). Effects of algal grazing and aggressive behavior of the fishes Pomacentrus lividus and Acanthurus sohal on coral reef ecology. Mar. Biol. 24: 131-136

Vooren, C. M. (1981). Photosynthetic rates of benthic algae from the deep coral reef of Curaçao. Aquat. Bot. 10: $143-154$

Wanders, J. B. W. (1976). The role of benthic algae in the shallow reef of Curaçao. I. Primary productivity in the coral reef. Aquat. Bot. 2: 235-270

Williams, A. H. (1981), An analysis of competitive interactions in a patchy back-reef environment. Ecology 62: 1107-1120

This article was submitted to the editor; it was accepted for printing on July 22, 1987 